«Системні технології» 4 (129) 2020 «System technologies»

DOI 10.34185/1562-9945-4-129-2020-05

УДК 65.011 .56

В.Ю. Куваєв, В.І. Нежурін, В.В. Стьопкін, Є.С. Нікітін

\title{
ДОСЛІДЖЕННЯ ЧАСТОТНО-РЕГУЛЬОВАНОГО ЕЛЕКТРОПРИВОДУ МЕХАНІЗМУ ПЕРЕСУВАННЯ ЕЛЕКТРОДІВ ПЕЧІ ДСП-3 ШЛЯХОМ МАТЕМАТИЧНОГО МОДЕЛЮВАННЯ
}

Анотація:В даній роботі отримані математичні моделі систем керування тиристорний перетворювач-двигун, скалярної та векторної для використання в електроприводі механізму пересування електродів печі ДСП-3. Дослідження трьох варіантів систем керування виконано з метою реалізації оптимальних перехідних процесів, що відповідають критеріям максимально можливої швидкодії та мінімізації динамічної похибки відпрацювання випадкових збурень.

Дугові сталеплавильні печі (ДСП) широко застосовуються в чорній металургії України для виробництва легованих сталей і сплавів. Основною вимогою до систем автоматичного регулювання (САР) режимами роботи ДСП є необхідність якісної стабілізації електричного режиму на кожній технологічній стадії процесу плавки [1]. Загальний вигляд дугової сталеплавильної печі ДСП-3 наведений на рис.1.

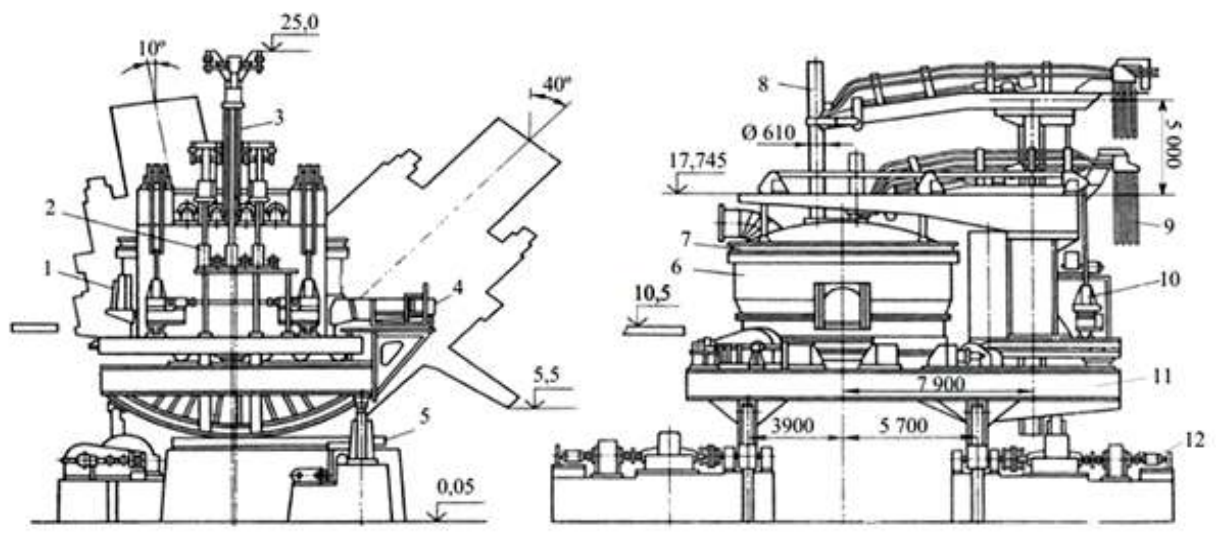

Рисунок 1 - Загальний вигляд дугової сталеплавильної печі ДСП-3:

1-робоче вікно; 2-механізм пересування електродів; 3- колонна електродотримача; 4 -зливний носок;5-фундаментна балка; 6 - кожух;

7 -свод; 8- електрод; 9- кабельна гірлянда; 10 - механізм підйому своду;11 люлька; 12- привод нахилу печі

(C) Куваєв В.Ю., Нежурін В.І., Стьопкін В.В., Нікітін Є.С., 2020 
«Системні технології» 4 (129) 2020 «System technologies»

Діючі ДСП, наприклад, ДСП-3 обладнана автоматичними регуляторами потужності дуг АРДМ-Т. Основною задачею АРДМ-Т є регулювання активної електричної потужності, що здійснюється зміною напруги пічного трансформатора при пересуванні електродів. При пересуванні електрода змінюється також довжина дуги, що відповідно змінює напругу дуги, силу струму та активну потужність печі. Автоматичні регулятори дугових печей реагують на відхилення повного опору фази від заданого значення. Використання цього параметру дозволяє легко запалювати дугу, підтримувати потужність печі, знизити коливання живлячої напруги. Основні вимоги, що висуваються до регулятора потужності дугової печі наступні: зона нечутливості регулятора повинна бути не більш 3-6\% в період розплавлення та 2-4\% в інші періоди плавки; швидкодія, яка забезпечує ліквідацію короткого замкнення або обриву дуги за 1,5-3 с; виключення зайвих пересувань електродів при короткочасних порушеннях режиму роботи печі; можливість достатньо плавної зміни потужності печі в межах 20-125 \% від номінальної з точністю до 5\%, та ін. [5]. 3 урахуванням цього, найбільш поширеними є регулятори потужності АРДМ-Т, які можуть встановлюватися на печах ємністю до 200 т. Регулятор виконано на базі комплектних тиристорних перетворювачів постійного струму 3 роздільним керуванням. Вони забезпечують час розгону приводу 0,6 с, зона нечутливості має 2 фіксовані значення 5 та 7\%, швидкість пересування електродів - до 2,5 м/хв ( з електромеханічним приводом ).

Відомі літературні джерела, зокрема [2], яке присвячено модернізації системи керування автоматичним регулятором АРДМ-Т, має на меті детальний аналіз недоліків та переваг систем керування регуляторами, пропонує напрями модернізації діючих регуляторів за рахунок введення додаткових блоків, параметри яких аналітичними або кореляційними відношеннями пов'язані 3 електричними та технологічними режимами роботи дугових електропечей, наводить алгоритми дії та принципи програмування цих систем керування. Дослідження виконані за допомогою математичного моделювання, основною метою приведених розробок $є$ побудова оптимальних систем керування діючими регуляторами з метою підвищення техніко-економічних показників виробництва продукції. 
«Системні технології» 4 (129) 2020 «System technologies»

Можливість використання частотно-регульованого приводу механізму пересування електродів регулятора АРДМТ-Т в загальному вигляді проаналізовано в роботі [3], де доцільність його використання обгрунтовано 3 точки зору енергозбереження засобами електроприводу. В роботі [4] вважають, що особливістю ДСП як об’єктів керування є надто складний математичний опис режимів і безперервні випадкові зміни параметрів, що не дає змоги на основі класичної теорії автоматичного керування реалізувати оптимальні та адаптивні до зміни параметрів закони руху електродів. В роботі ставиться задача комплексного дослідження показників динаміки діючого привода ДСП-200, електротехнологічної ефективності та електромагнітної сумісності. Розроблена математична модель, орієнтована на систему живлення та регулятор АРДМТ-12 ДСП-200, який враховує динамічні вольт-амперні характеристики дуг. При цьому підвищується точність системи автоматичного регулювання(САР) та поліпшуються інтегральні показники динамічної точності регулятора. Виконано оцінку показників якості динаміки електричного режиму роботи печі при використанні одно- та двоконтурної САР.

Однак, у теперішній час відсутні матеріали, присвячені дослідженню та порівняльному аналізу динамічних властивостей привода пересування електродів дугової печі на основі систем:тиристорний перетворювач - двигун (ТП-Д) та перетворювач частоти - асинхронний двигун (ПЧ-АД) з регулятором АРДМ-Т. Структурна схема системи керування однією фазою дугової печі за системою ПЧ-АД наведена на рис.2.

3 урахуванням цих досліджень метою даної роботи є розробка структурної схеми моделі привода механізму пересування електродів 3 автоматичним регулятором АРДМТ-Т на прикладі ДСП-3 фасоноливарного цеху ПрАТ «Дніпровський металургійний завод», м. Дніпро на основі використання сучасних перетворювачів частоти, складання математичної моделі діючого привода та запропонованого, порівняльний аналіз показників якості перехідних процесів за струмом та кутовою швидкістю, виконаним за системами ТП-Д та ПЧ-АД. 
«Системні технології» 4 (129) 2020 «System technologies»

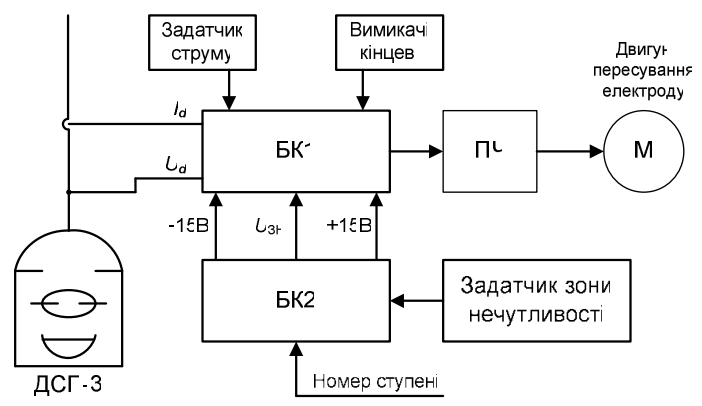

Рисунок 2 - Структурна схема системи керування однією фазою дугової печі за системою ПЧ-АД:

БК1,БК2 - блоки керування, ПЧ - перетворювач частоти

3 метою розв’язання цих питань, авторами запропонований електропривод механізму пересування електродів з АРДМ-Т на основі ПЧ-АД, що дозволяє істотно збільшити точність регулювання швидкості, технологічний діапазон зміни потужності печі, підвищити швидкодію електроприводу, яка задовольняє вимогам до регулятора ДСП [5]. В якості приводного запропоновано асинхронний двигун 6AMУ100SP та частотний перетворювач VFD22C43A, який дозволяє реалізувати як скалярне, так і векторне керування приводом.

До складу блоку керування БК1 (рис.2) входять: датчик струму,датчик напруги, вузол завдання струму, вузол порівняння, вузол формування сигналу для переходу у релейний режим роботи регулятора, вузол обмеження максимального рівня сигналу на опускання електроду, вузол забезпечення автономності регулюючих збурень при коротких замкненнях, вузол обмеження опускання та підйому електродів при наїзді на кінцевий вимикач, вузол зняття сигналу на завдання струму при обриві дугового розряду.

Блок керування БК2 включає: стабілізоване джерело живлення \pm 15 В, вузол формування сигналу завдання зони нечутливості, вузол формування сигналу корекції за номером ступені напруги пічного трансформатора. Диференційний принцип роботи реалізовано в блоці БК1, де формується сигнал за рівнянням:

$$
\mathrm{aU} \mathrm{U}_{\text {д }}-\mathrm{b}\left(\mathrm{I}_{\text {д }}+\mathrm{I}_{3}\right)=\Delta \mathrm{U},
$$

де a,b - коефіцієнти пропорційності, $\mathrm{U}_{\text {д }}$ - напруга на електроді, $\mathrm{I}_{\text {д }}$ - струм дуги, $\mathrm{I}_{3}$ - струм завдання (встановлюється за датчиком струму). 
«Системні технології» 4 (129) 2020 «System technologies»

Для забезпечення автоматичного запалювання дуги необхідно виконання умови $\mathrm{I}_{д}<5 \% \mathrm{I}_{\text {ном}}, \mathrm{I}_{3}=0$. Якщо сигнал відхилення більше заданого

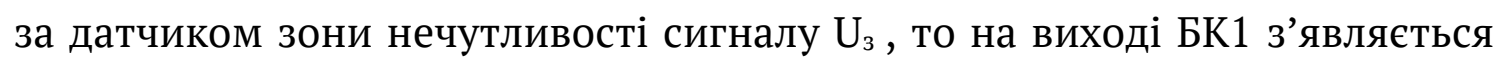
сигнал керування $\mathrm{U}_{\mathrm{K}}=\Delta \mathrm{U}-\mathrm{U}_{3}$, який подається на вхід перетворювача в якості сигналу завдання частоти обертання двигуна приводу пересування електродів.

На рис.3 наведено статичну характеристику регулятора при підйомі та опусканні електроду дугової печі.

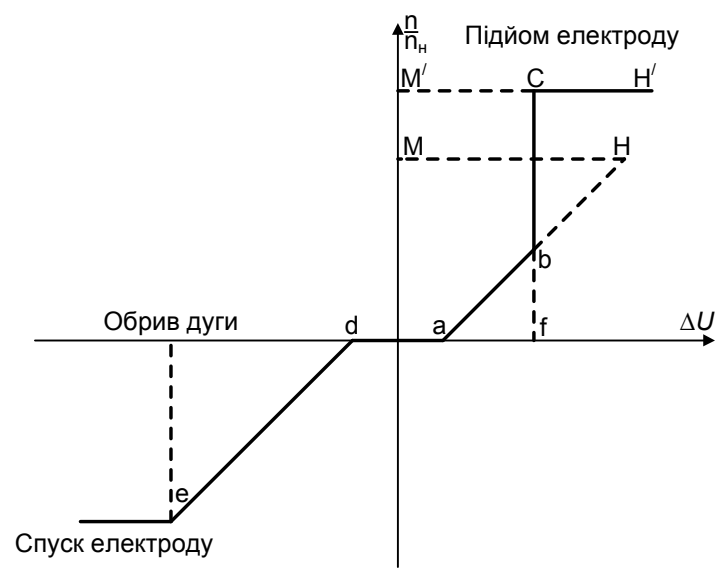

Рисунок 3 - Статична характеристика регулятора при підйомі та опусканні електроду

Відрізки 0 - $d$ та 0 - $a$ характеризують зону нечутливості регулятора на опускання та підйом електрода. При опусканні електроду регулятор працює у пропорційному режимі - відрізок $d$-e. При підйомі електроду передбачено два режими: пропорційний - відрізок $a-b$ та релейний відрізок $b$-c. Якщо сигнал відхилення $\Delta U$ більше,ніж відрізок $0-f$, запускається інтегратор, розташований в блоці БК1 і сигнал керування $\mathrm{U}_{\mathrm{k}} 3$ затримкою в часі збільшується до рівня, який відповідає максимальній швидкості підйому електродів.

Структурна схема моделі електропривода механізму пересування електродів наведена на рис.4. До складу моделі входять три основних блоки: система керування на постійному струмі I (DCCONTROLSYSTEM) до складу якої входить двигун постійного струму та тиристорний перетворювач із системою керування; векторна система керування III(VECTORCONTROLSYSTEM) та скалярна система керування 44 
«Системні технології» 4 (129) 2020 «System technologies»

II(SCALARCONTROLSYSTEM) із асинхронним двигуном з короткозамкненим ротором та перетворювачем частоти. На осцилографи Scope1, Scope2 виведені сигнали завдання на швидкість, струми двигунів та кутові швидкості двигунів. Моделювання виконано у відносних одиницях.

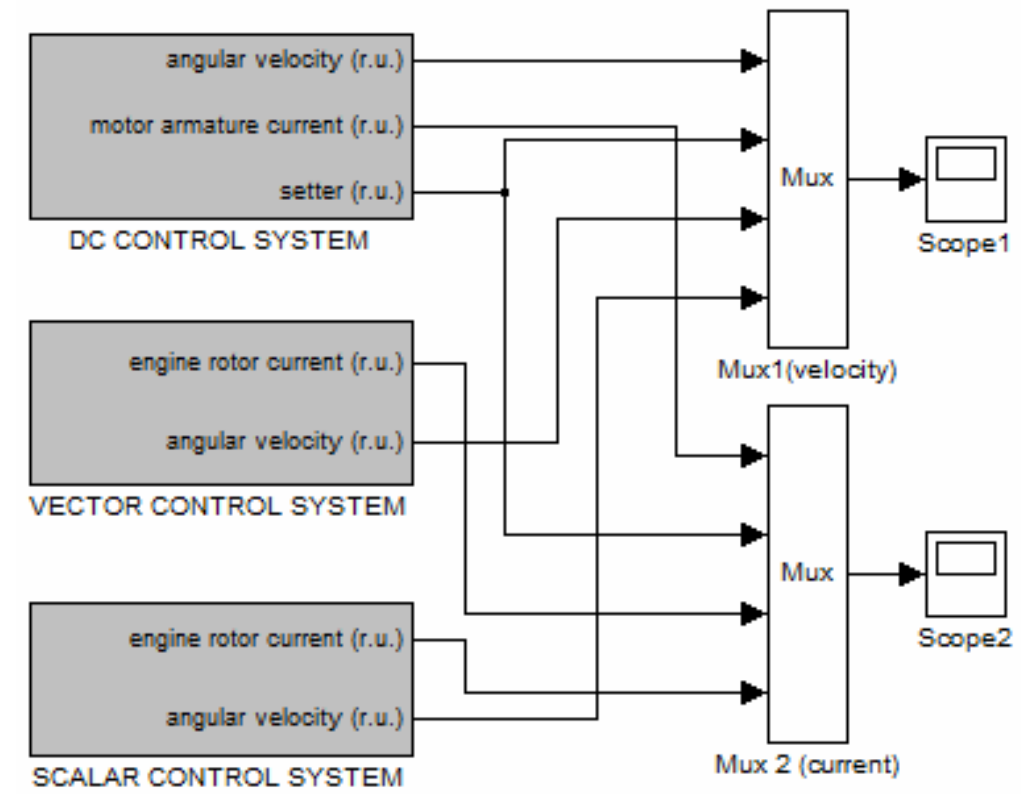

Рисунок 4 - Структурна схема моделі електропривода механізму пересування електродів

Графіки перехідних процесів за струмом та кутовою швидкістю двигунів наведені на рис.5а, б. На рис.5а відображені такі координати електроприводів: 1 - завдання; 2 - струм двигуна постійного струму; 3 струм двигуна змінного струму системи II; 4 - струм двигуна змінного струму системи III. На рис.5,б відображені координати електроприводів: 1 - завдання; 2 - кутова швидкість двигуна постійного струму системи I; 3 - кутова швидкість двигуна змінного струму системи II; 4 - кутова швидкість двигуна змінного струму системи III. За швидкодією найкращій результат у системі III - векторній.

Векторна система керування виконана за комбінованим принципом 3 розділенням каналів керування швидкістю та потокозчепленням. Присутні нелінійні зв’язки об’єкта керування компенсовані додатковими перехресними зворотними зв’язками між контурами швидкості, потокозчеплення та струмів. Скалярна система керування II має значну коливальність за струмом та швидкістю та не забезпечує необхідну виISSN 1562-9945 (Print) 
«Системні технології» 4 (129) 2020 «System technologies»

могу розгону електропривода за 0,6с. Система постійного струму I та векторна система III забезпечують розгін електропривода за час 0,35c без перерегулювання за швидкістю.

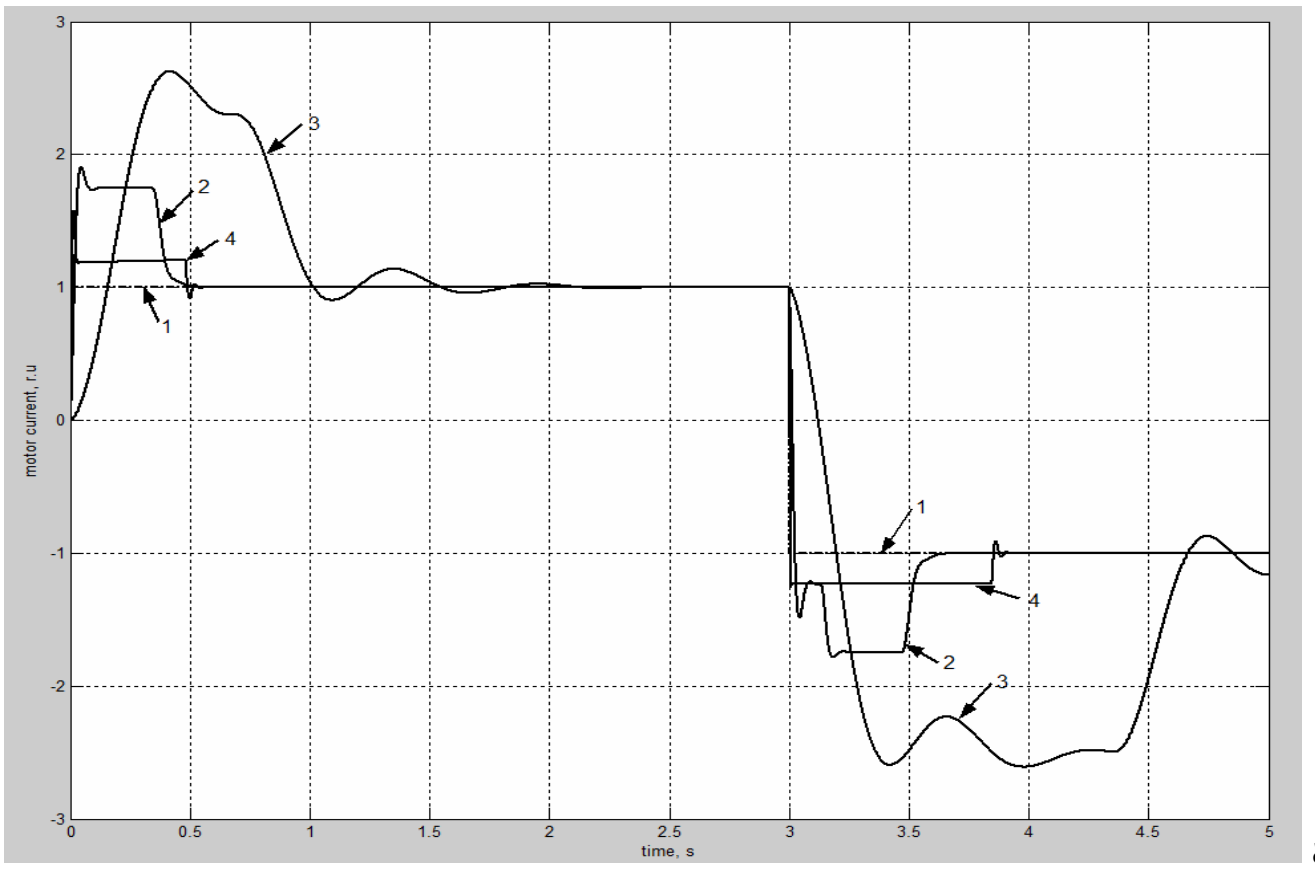

a)

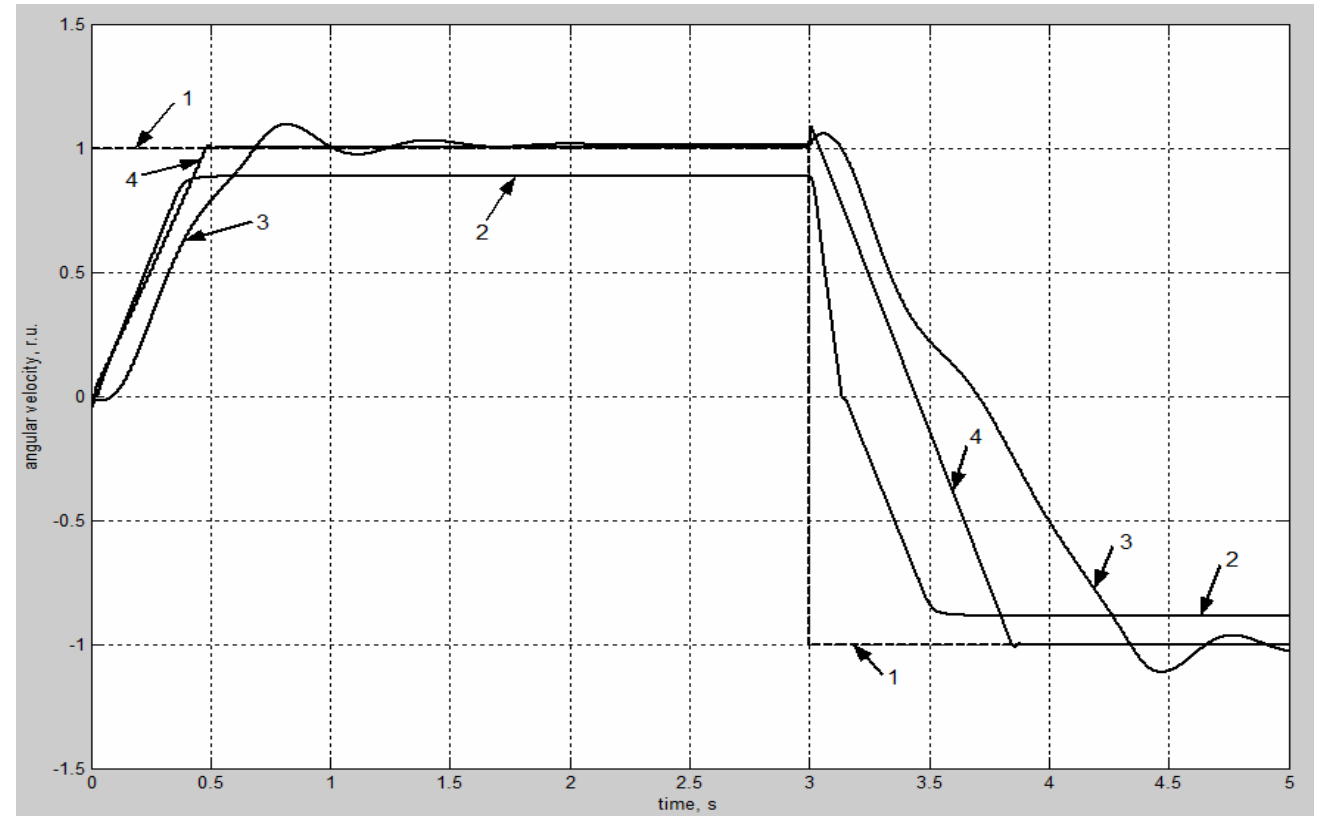

б)

Рисунок 5 - Графіки перехідних процесів за струмом (1-4, а) та кутовою швидкістю двигунів $(1-4,6)$ 
«Системні технології» 4 (129) 2020 «System technologies»

Дослідження систем керування (I-III) на імітаційній моделі підтвердило, що векторна система керування задовольняє вимогам швидкодії за тривалістю розгону 0,6с та може бути використана для керування електроприводом механізму пересування електродів печі ДСП-3.

Реалізація електроприводу механізму пересування електродів ДСП-3 з частотним перетворювачем $є$ достатньо перспективним напрямом модернізації і, як показали дослідження з використанням математичного моделювання, має кращі результати за існуючу систему керування постійного струму І. Отримані результати, в перспективі, дають можливість виконання на моделях (I-III) математичних експериментів 3 дослідження показників динаміки регулювання координат електропривода.

\section{ЛІТЕРАТУРА / ЛИТЕРАТУРА}

1. Минеев А.Р. Моделирование электротехнологических процессов и установок / А. Р. Минеев, А. И. Коробов, М. Я. Погребисский. - М: Спутник+, 2004. - 124 с.

2. Паранчук Я.С. Дослідження оцінок факторів впливу на електричний режим дугової сталеплавильної печі з регулятором АРДМ-Т / Я. С. Паранчук, В. Р. Головач. // Науковий вісник Вінницького політехнічного інституту. - 2014. - №3. - С. 80-84.

3. Попов А.Е. Применение частотного управления приводом перемещенияэлектродов в автоматических регуляторах дуговыхэлектропечей / A. Е. Попов. // Известия вузов, серия "Электромеханика". - 2005. - №2. - С. 78-80.

4. Розвиток методів та засобів комп'ютерного моделювання для дослідження електричних режимів дугової сталеплавильної печі / O. Ю.Лозинський, Я. С. Паранчук, Р. Я. Паранчук, Ф. Д. Матіко. // Науковий вісник національного технічного університету "Харківський політехнічний інститут", серія "Електротехніка і електромеханіка". - 2018. - №3. С. 208-209.

5. Мицьковський М.В. Частотно-регульований електропривод механізму пересування електродів регулятора потужності дугової сталеплавильної печі [Електронний ресурс] / М.В. Мицьковський, В.Ю. Куваєв, В.І.Нежурін // V міжнародна науково-технічна конференція Комп'ютерне моделювання та оптимізація складних систем КМОСС-2019. - 2019. - Режим доступу до ресурсу: http://orgconf.com/event/conf-CMOSS2019. 
«Системні технології» 4 (129) 2020 «System technologies»

\section{REFERENCES}

1. Mineev A. R. Modeling of electrotechnological processes and installations / A. R. Mineev, A. I. Korobov, M. Y. Pogrebissky. - M: Sputnik +, 2004 .- 124 p.

2. Paranchuk R.Y. Research of the factor sofin fluence on the electric mode of th earcsteel making furnace with the ARDM-T controller / R. Y. Paranchuk, V. R. Golovach. // Scientific Bulletin of Vinnitsa Polytechnic Institute. - 2014. №3. - P. 80-84.

3. A. Popov. Application of frequency control of the electrode displacement drive in automatic controllers of electric arc furnaces / A. E. Popov. // University proceedings, series "Electromechanics". - 2005. - No. 2. - P. 78-80.

4. Development of methods and tools of computer simulation for the study of electric modes of arc steelmaking furnace / O. Yu. Lozynsky, Ya. S. Paranchuk, R. Ya. // Scientific Bulletin of the National Technical University "Kharkiv Polytechnic Institute", series "Electrical Engineering and Electromechanics". 2018. - №3. - P. 208-209.

5. Development of methods and tools of computer simulation for the study of electric modes of arc steelmaking furnace / O. Yu. Lozynsky, Ya. S. Paranchuk, R. Ya.// Scientific Bulletin of the National Technical University "Kharkiv Polytechnic Institute", series "Electrical Engineering and Electromechanics". 2018. - №3. - P. 208-209.

Received 24.02.2020. Accepted 26.02.2020.

\section{Исследование частотно-регулируемого электропривода механизма перемещения электродов печи ДСП-3 путем математического моделирования}

Рассмотрена литература, посвященная модернизации систем управления и частотно-регулируемому приводу перемещения электродов дуговой печи. Исследование предлагаемых приводов выполнено путем математического моделирования. Модели системы управления приводом перемещения электродов для действующего и предлагаемого вариантов со скалярным и векторным управлением исполнены в программном продукте MATLAB. Исследование на имитационной модели подтвердило, что привод по системе ПЧ-АД с векторным регулированием скорости обеспечивает длительность переходных прочессов на 16\% меньше, чем система ТП-Д, а статическая ошибка составляет 0\% против 3\%. Реализация электропривода механизма перемещения электродов на основе преобразователя частоты с векторным управлением и асинхронным двигателем является перспективным направлением модернизации.

Researching of frequency-controlled electric drive of the mechanism of movement of electrodes of ASF-3 furnace by mathematical modeling

Well-known studies of the drive of electrode movement are performed using mathematical modeling, in particular, the main purpose of the above developments is the construction of optimal control systems of operating regulators of electric arc furnaces in order to improve the technical and economic performance of production. The possibility and expediency of using a frequency-controlled actuator of the mechanism of electrode movement in the general form of use is substantiated from the point of view of energy saving by means of the actuator. The purpose of this work is a detailed development of the structural and functional scheme of the drive 
«Системні технологіï» 4 (129) 2020 «System technologies»

mechanism for the movement of electrodes with an automatic controller on the example of ASF3 furnace molding shop DMZ based on the use of modern frequency converters, compilation of mathematical model of the actuator and proposed, comparative analysis of the quality of the drive control system, according to $D C$ and AC. Asynchronous motor 6AMU100SP and frequency converter VFD22C43A are offered as a drive, which allows implementing both scalar and vectoring control of the actuator. On the basis of the analysis of the technological process, the algorithm of operation of the electric drive of the mechanism of movement of the electrodes of the furnace, a functional scheme of automation on the AC system was drawn up. Literature devoted to the modernization of control systems, controllers and variable-frequency drive mechanism for movement of the electric arc furnace electrodes are considered. The research of current and proposed drives through mathematical modeling. Models of the control system of the electrode mechanism for the basic and proposed variants with scalar and vectoring control are made in the MATLAB software. Survey on simulation models confirmed that the system provides vectoring control speed transient time $16 \%$ less than the DC system and a static error is $0 \%$ to $3 \%$. The implementation of the electric drive of the mechanism of movement of electrodes based on the frequency converter with vector control and an induction motor is a promising direction of modernization.

Куваев Виктор Юрьевич - старший преподаватель кафедры электротехники и электропривода НМетАУ, г.Днепр.

Нежурин Вадим Ильич - к.т.н., доцент кафедры электротехники и электропривода НМетАУ, г.Днепр.

Степкин Василий Владимирович - к.т.н., доцент кафедры электротехники и электропривода НМетАУ, г.Днепр.

Никитин Евгений Сергеевич - студент группы АП01-15 электрометаллургического факультета Национальной металлургической академии Украины, г.Днепр.

Куваєв Віктор Юрійович - старший викладач кафедри електротехніки та електропривода НМетАУ, м.Дніпро.

Нежурін Вадим Ілліч - к.т.н., доцент кафедри електротехніки та електропривода НМетАУ, м.Дніпро.

Стьопкін Василь Володимирович - к.т.н., доцент кафедри електротехніки та електропривода НМетАУ, м.Дніпро.

Нікітін Євген Сергійович - студент гр. АП01-15 електрометалургійного факультету Національної металургійної академії України, м. Дніпро.

Kuvaev Viktor - Senior Lecturer, Department of Electrical Engineering and Electric Drive NMetAU, Dnepr.

Nezhurin Vadim - Ph.D., associate professor of the Department of Electrical Engineering and Electric Drive NMetAU, Dnepr.

Stopkin Vasyl - Ph.D., associate professor of the Department of Electrical Engineering and Electric Drive NMetAU, Dnepr.

Nikitin Evgeny - student of the group AP01-15 electrometallurgical faculty of the National metallurgical academy of Ukraine, Dnepr. 